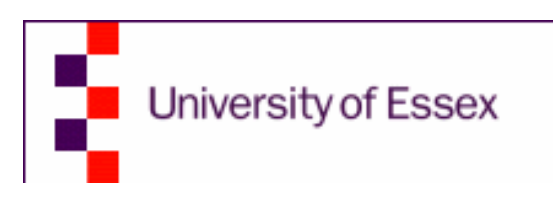

SCHOOL OF ACCOUNTING, FINANCE AND MANAGEMENT

\title{
DOES COMPETITION LEAD TO EFFICIENCY? \\ THE CASE OF EU COMMERCIAL BANKS
}

\author{
Barbara Casu \\ Claudia Girardone \\ University of Essex
}

Cass Business School, City University

Discussion Paper No. 07-01

\section{$¥$}




\title{
Does Competition Lead to Efficiency? The Case of EU Commercial Banks
}

\author{
Barbara Casu $^{\dagger}$ \\ Cass Business School, City University \\ b.casu@city.ac.uk \\ Claudia Girardone ${ }^{*}$ \\ University of Essex \\ cgirardone@,essex.ac.uk
}

\begin{abstract}
$\underline{\text { Abstract }}$
In Europe, the past twenty years saw a process of liberalisation, deregulation and unprecedented financial sector reform whose main aims were to increase competition and remove all remaining barriers to the integration of EU banking sectors. However, the recent acceleration in the consolidation process has raised concerns about the potential implications for public policies deriving from increased market power. Using bank level balance sheet data for commercial banks in the major EU banking markets, this paper aims to shed some light on the recent developments in competition, concentration and bank-specific efficiency levels. Furthermore, using a Granger-type causality test estimations this study aims to investigate the relationship between competition and efficiency in banking markets. Our findings suggest a negative causation between efficiency and competition, whereas the causality running from competition to efficiency, although positive, is relatively weak.
\end{abstract}

Keywords: Competition, Efficiency, Market Power, Granger Causality, EU Commercial Banks.

JEL classification: G21; D24

\footnotetext{
${ }^{\dagger}$ Barbara Casu, Faculty of Finance, Cass Business School, City University, 106 Bunhill Row, London EC1Y 8TZ, UK. Tel. +44 (0) 2070405283 or email: b.casu@,city.ac.uk

* Claudia Girardone, School of Accounting, Finance and Management, University of Essex, Wivenhoe Park, Colchester, CO4 3SQ. Tel. +44(0) 1206874156 or email: cgirardone@essex.ac.uk
} 


\section{Does Competition Lead to Efficiency? The Case of EU Commercial Banks}

\section{Introduction}

Competition is generally accepted as a positive force in most industries; it is supposed to have a positive impact on an industry's efficiency, quality of provision, innovation and international competitiveness. However, the issue of competition in banking has always been controversial, as the perceived benefits from increased competition have to be weighted against the risks of potential instability. As a consequence, the banking industry has been historically heavily regulated. Furthermore, the existence of frictions in banking markets (for example, the existence of entry barriers and asymmetric information) causes the welfare theorems associated with perfect competitions not to be directly applicable to banking and allows room for the exercise of market power (Vives, 2001). Nevertheless, a healthy degree of rivalry is considered necessary for the dynamic efficiency of an industry and this principle is at the basis of the trend towards fostering greater competition in banking markets all over the world.

The past twenty years saw a process of liberalisation, deregulation and unprecedented financial sector reform both in developing and developed countries. In the European Union, the aim of regulatory developments, which include movements towards the creation of a single market for financial services, was to foster competition in order to improve the productivity, efficiency and profitability of the banking systems and also to increase both national and international competitiveness. The European Commission (EC), in its recent White Paper on Financial Services Policy (2005-2010) has stated that its principal objectives include: “To consolidate dynamically towards an integrated, open, inclusive, competitive, and economically efficient EU financial market and to remove the remaining economically significant barriers so financial services can be provided and capital can circulate freely throughout the EU at the lowest possible cost..." (SEC(2005) 1574). The EC believes that the aim of increased financial integration has been driven forward by the success of the Financial Services Action Plan 1999-2005 (FSAP), resulting in improvements in the financial industry's overall performance: higher liquidity, increased competition, sound profitability and stronger financial stability. The EC is also keen to further 
enhance competition to encourage additional consolidation and to boost the efficiency of panEuropean financial markets.

Banks responded to the new operating environment by adapting their strategies, seeking new distribution channels and changing their organisational structures. Increased competition has also been considered the main driving force behind the acceleration in the recent consolidation process; which is raising concerns about increased concentration in the banking sector and its potential implications for public policy. The aggregate number of credit institutions continued declining, confirming the trend of market consolidation. At the end of 2005, there were 8,684 institutions representing a decrease of $10.9 \%$ relative to 2001 . Consolidation has proceeded even faster in the euro area with a decrease of $12.5 \%$ since 2001 (ECB, 2006). In past years, concentration operations in the EU banking sector have been predominantly of a domestic nature. Between 1993 and 2003, the number of mergers and acquisitions involving domestic credit institutions represented about $80 \%$ of total consolidation activity in the EU (Walkner and Raes, 2005). However, the pace of domestic consolidation has recently slowed down, whereas the value of cross-border bank M\&A has been rising, reaching record levels in 2005. EU-wide consolidation has been under way for some time: since the mid-1990s European banks have spent $€ 158$ bn on 274 cross-border M\&A deals, involving other European banks (for example, HSBC and Credit Commercial de France, Barclays' acquisition of Banco Zaragozano, Unicredit's acquisition of HVB and BSCH acquisition of Abbey, ABN-AMBRO and Banca Antonveneta) and there are reasons to believe the trend will gather pace (PWC, 2006). The degree of concentration of EU banking systems continues to rise: in the period 2000-2005 the five largest credit institutions increased their share of total assets from $37.8 \%$ to $42.3 \%$ in the EU (from $39.1 \%$ to $43 \%$ in the euro area) (ECB, 2006).

However, the impact of consolidation on banking-sector performance remains controversial (see Amel et al., 2004). In particular, the debate on the competition and market power effects of bank concentration and their relationship with profitability and efficiency issues has raised great interest among academics, policy-makers and anti-trust authorities. Policymakers are faced with the contrasting issues as to whether competitive forces are posing a threat for the sector stability or whether the consolidation wave poses a threat to competition in the sector. Indeed, these issues are highly interrelated and often intertwined and, given the unique role of banks in the economy and the potential non-trivial implications for welfare, they deserve special attention. 
The study of bank competition and its effect on the concentration, efficiency, profitability and, indirectly, stability of the EU banking sector is therefore of relevance in a period of renewed regulatory efforts to remove the remaining barriers and of increased domestic and cross-border M\&As. This paper aims to investigate the dynamics of both competition and efficiency in EU banking markets since the year 2000. Concentrating on the commercial banking sector of the five main EU banking markets (France, Germany, Italy, Spain and the UK), this study evaluates cost efficiency using both parametric (SFA) and non parametric (DEA) approaches. We test the degree of competition by using both structural (concentration ratios, Herfindhal Hirshman Index) and nonstructural methods, the Panzar-Rosse H-Statistic and the Lerner Index. Furthermore, using dynamic panel data Granger-type causality test estimations, this study aims to investigate the relationship between competition and efficiency in banking markets. Whereas a positive relationship between competition and efficiency is often assumed, the specific characteristics of banking markets (i.e. entry barriers, sunk costs, information asymmetries) may lead to excessive market power of efficient banks, therefore reducing competition. Our findings suggest a negative causation between efficiency and competition, whereas the causality running from competition to efficiency, although positive, is relatively weak. These results pose further questions for European regulators, as they might be faced by a trade-off between competition and efficiency.

The remainder of the paper is structured as follows. Section 2 reviews the main literature on competition and efficiency in banking. Section 3 describes data and empirical methods used. Section 4 discusses the results and Section 5 concludes.

\section{Competition and Efficiency in European Banking}

Over the past twenty years, the deregulation and market integration processes, coupled with advances in information technologies, have been a steady feature of EU banking markets and have given way to a profound transformation and restructuring of the banking industry, which materialised in enhanced consolidation and a move away from the traditional intermediation business into more profitable investment services. The analysis of the relationship connecting deregulation, market enlargement, competition, consolidation, profitability and efficiency is one of relevance to researchers and policymakers. The issue of competition has been widely researched in the industrial organisation literature from the 1980s onwards, evolving mainly in two directions: the 
structural and non-structural approaches. Traditional industrial organisation theory focuses of the Structure-Conduct-Performance (SCP) paradigm. Market structure is reflected in concentration ratios for the largest firms (CR ratios) and the Hirschman Herfindhal index (HH). This literature is essentially based on the assumption that concentration weakens competition by fostering collusive behaviour among firms (the so-called "collusion hypothesis"). Increased market concentration was found to be associated with higher prices and greater than normal profits (Bain, 1951). Smirlock (1985) and Evanoff and Fortier (1988) argue that higher profits in concentrated markets could be the result of greater productive efficiency. The existence of a link between market structure and efficiency was first proposed by Hicks (1935) and the quiet life hypothesis. Hicks (1935) argued that monopoly power allows managers a quiet life free from competition and therefore increased concentration should bring about a decrease in efficiency. Liebenstein (1966) argues that inefficiencies are reduced by increased competition as managers respond to the challenge. The efficient structure hypothesis (Demsetz, 1974) on the other hand, posits a reverse causality between competition and efficiency. According to the efficient structure hypothesis, more efficient firms have lower costs, which in turn lead to higher profits. Therefore, the most efficient firms are able to increase their market share, resulting in higher concentration. Firms may be exploiting greater Xefficiency (the so-called "efficiency hypothesis") or greater scale efficiency (the so-called "scale efficiency hypothesis"). Given that higher market concentration lowers competition, according to the efficiency hypothesis there should be an inverse relationship between competition and efficiency, thus reversing the causality running from efficiency to competition in the SCP paradigm. Berger (1995) finds some evidence that the efficiency hypothesis holds in US banking. In Europe, on the other hand, structural factors appear to be more important and the SCP hypothesis seems to hold (Goddard et al., 2001). However, the debate "collusion" versus "efficiency" has not yet been satisfactorily resolved (Goddard et al., 2007).

The non-structural approach, on the other hand, posits that factors other than market structure and concentration may affect competitive behaviour, such as entry/exit barriers and the general contestability of the market (Baumol et al. 1982; Bresnahan, 1989; Rosse and Panzar, 1977; Panzar and Rosse, 1987). These latter approaches have been developed in the context of the New Empirical Industrial Organisation (NEIO) literature. While tests of market power carried out employing the traditional SCP approach (and recent variations of it), observe the structure of the market (e.g. concentration levels, number of firms) and relate this to the conduct (e.g. pricing policies) and performance (e.g. ROA, ROE) of firms; in non-structural approaches empirical studies do not 
observe the competitive environment but they attempt to measure/infer it. Probably the most important advantage of non-structural approaches is that it cannot be assumed a priori that concentrated markets are not competitive because contestability may depend on the extent of potential competition and not necessarily on market structure. Another advantage of non-structural models is that there is no need to specify a geographic market, since the behaviour of individual banks gives an indication of their market power. Non-structural measures of competition are mainly based on the Lerner (1934) measure of monopoly power. Specifically, they include measures of competition between oligopolists (Iwata, 1974) and those that test for the competitive conditions in contestable markets (Bresnahan, 1982; Lau, 1982; Panzar and Rosse, 1987). Several recent empirical applications point to the need of a structural contestability approach when studying the degree of competitiveness in the banking industry (see Claessens and Laeven, 2004). Relatively new research warns that bank size and types may affect competitiveness differently and that using only one measure may not be sufficient for inferring on the true degree of competition (Berger et al., 2004).

Both the SCP and the NEIO are based on static models of competitive equilibrium. On the other hand, the persistence of profit (POP) hypothesis (Mueller, 1977, 1986) posits that if entry and exit are sufficiently free, it would quickly eliminate any abnormal profit and all firms' profits would tend to converge toward the same long run average. However, if abnormal profits tend to persists from year to year, then there might be barriers to entry or banks might be exploiting monopoly power.

There is a vast literature on the measurement of cost structure and efficiency in banking and on the determinants of efficiency. The early bank efficiency literature shows that before deregulation banking markets were often characterised by the presence of many institutions operating at a nonoptimal scale with relatively high excess capacity (see the reviews by Berger and Humphrey, 1997 and Goddard et al., 2001). Such banks could survive mainly because of the lack of competitive pressures and the fact that, in some cases, the domestic authorities, while acting as protectors of their banking sectors, were keen on maintaining a large number of banks in their systems. With deregulation and higher competition, the process of concentration accelerated so that banks could operate at a better (and more efficient) scale that allowed them to earn higher profits. In some cases, takeovers could even be considered as a 'natural outcome' of a competitive game that had positive externalities because it could prevent the failure of significantly inefficient banks (Grillo, 2005). As 
a result of such 'dynamic' competition, the correlation between bank-specific profitability and efficiency should be positive, although higher concentration levels in the banking sector could subsequently limit the welfare gains through the loss in competition. Indeed a more static approach to competition suggests that banks operating in a concentrated market may be induced to use their market power to gain extra profits in an attempt to offset the inefficiencies derived by the lack of competitive pressures. Here the correlation between profitability and efficiency should be either zero or negative because less efficient banks with more market power will be able to gain extra profits. If we refer to the extant efficiency literature, banks typically encounter relatively large scale diseconomies once they exceed a certain 'optimal' size (Amel et al., 2004). Similarly, the corporate finance literature suggests that on average bank M\&As do not offer improvements in either efficiency measures or better stock market returns. While evidence of efficiency gains within banks that have consolidated is not clear-cut, a number of analyses suggest that banking consolidation tends to increase customer welfare by improving lending rates and credit access for borrowers, as well as - in the longer run - raising deposit rates (Grillo, 2005).

Only a handful of studies directly address the issue of the relationship between the intensity of competition and efficiency. It was expected that increased competition would in turn foster efficiency by providing incentives to managers to cut costs in order to remain profitable. Recent research has however indicated that the relationship between competition and banking system performance is more complex and that the view that competition is unambiguously good is more naïve in banking than in other industries (Claessen and Leaven, 2004). The empirical evidence on the links between concentration and banking sector efficiency does not suggest an unambiguously positive - or negative - relationship (Demirgüç-Kunt and Levine, 2000). Furthermore, there are conflicting results on the impact of increased bank concentration - through M\&As - on efficiency, deposit rates and bank profitability (Berger and Humphrey, 1992; Pilloff, 1996). Based on European banking data, Casu and Girardone (2006) and Weill (2005) find an inverse relationship between competition and efficiency. They find little evidence that banking system concentration negatively relate to competitiveness but suggest that the most efficient banking systems are also the least competitive. It may be the case that larger size banks have been able to cut cost, exploit both economies of scale and X-efficiencies, and achieve a degree of market power in their local markets, therefore increasing both prices and profits. This may indicate that that the pro-competitive deregulation of the EU banking markets might have led to increased market power for the most efficient banks, therefore lowering the pressures initially resulting from increased competition. 
This study contributes to the literature both by extending the analysis of the relationship between bank competition, concentration and efficiency to a cross-section of countries and by testing the direction of the causal relationship between competition and efficiency. In a bi-variate framework, the first variable is said to cause the second variable in the Granger sense if the forecast for the second variable improves when lagged values for the first variable are taken into account (Granger, 1969). Though originally designed for pairs of lengthy time series, Granger tests are increasingly used to evaluate causal relationships in panel data. The extension of the original Granger methodology to panel data has the potential to improve upon the conventional Granger analysis for all of the reasons that panel analysis is generally preferable to cross-sectional or traditional time series analysis (see Greene, 2003). The introduction of a panel data dimension permits the use of both cross-sectional and time-series information to test any causality relationships between two variables. In this paper, we employ dynamic panel data methods; specifically we use the 'difference' and 'system' (or 'combined') Generalised Method of Moments (GMM) procedures developed by Holtz-Eakin et al. (1988), Arellano and Bond (1991), Arellano and Bover (1995) and Blundell and Bond (1998). Our findings suggest that in the majority of cases the Granger coefficient is negative, thereby indicating that cost efficiency negatively Granger-causes competition (i.e. an increase in bank efficiency Granger-causes a decrease in competition). On the other hand, the causality running from competition to efficiency, although positive, is relatively weak. These results pose additional questions for competition policies. Regulatory initiatives aimed at further enhancing competition in EU banking should be aware of its possible adverse effects on efficiency. Decreases in bank efficiency can either be a signal that banks are struggling under excessive competition, with serious implications for the sector stability, or that they are reacting to competition by increased market power. Indeed, market power, as Vives (2002) points out, could be beneficial in banking as it provides incentives for banks to undertake less risky strategies.

\section{Methodology and Data}

\subsection{NEIO Measures of Competition: H-statistics and Lerner Index}

The H-statistics and Lerner Index are non-structural indicators of the degree of market competition that were developed in the context of the NEIO (e.g. Iwata, 1974; Baumol et al. 1982; Bresnahan, 1989; Rosse and Panzar, 1977; Panzar and Rosse, 1987). The H-statistics (Panzar and Rosse, 1987) 
is calculated using a reduced form revenue equation and measures the sum of elasticities of total revenue of the firm with respect to the firm's input prices as follows:

$$
H=\sum_{k=1}^{m} \frac{\partial R_{i}^{*}}{\partial w_{k i}} \frac{w_{k i}}{R_{i}^{*}}
$$

where $\mathrm{R}_{\mathrm{i}}$ refers to revenues of bank $\mathrm{i}$ (* indicates equilibrium values) and $\mathrm{w}_{\mathrm{i}}$ is a vector of $\mathrm{m}$ factor input prices of bank i. Market power is measured by the extent to which a change in factor input prices $\partial w_{k i}$ is reflected in the equilibrium revenues $\partial R_{i}^{*}$ earned by bank $\mathrm{i}$.

Inputs and outputs are defined using Sealey and Lindley (1977)'s intermediation approach as follows: deposits, labour and capital are inputs to the production process of banks while total loans and securities are outputs. A fixed effects panel data model is run to estimate the following reduced form revenue equation in order to derive the Panzar-Rosse H-statistic:

$$
\begin{aligned}
& \ln T R_{i t}=\beta_{1} \ln P_{1, i t}+\beta_{2} \ln P_{2, i t}+\beta_{3} \ln P_{3, i t}+\gamma_{1} \ln E Q A S T_{i t}+\gamma_{2} \ln A_{S T}+ \\
& +\gamma_{3} \ln L O A N A S T_{i t}+\gamma_{4} \ln D E P_{i t}+\gamma_{5} \ln O B S A S T_{i t}+\varepsilon_{i t}
\end{aligned}
$$

for $t=1, \ldots T$, where $\mathrm{T}$ is the number of periods observed and $i=1, \ldots I$, where $\mathrm{I}$ is the total number of banks. Subscripts $i$ and $t$ refer to bank $i$ at the time $t$. The dependent variable is $\operatorname{lnTR}$, which is total revenue over total assets and thus accounts for both the banks' interest- and non-interest income. The variable is divided by total assets in order to account for size differences. Consistently with the intermediation approach, we assume that banks use three inputs, labour, deposits and capital. $\ln \mathrm{P}_{1}$ is the average cost of labour (personnel expenses/total assets); $\ln \mathrm{P}_{2}$ is the average cost of deposits (interest expenses/customer and short-term funding); and $\ln \mathrm{P}_{3}$ the average cost of capital (total capital expenses/total fixed assets). The equation also includes a set of explanatory variables which reflect differences in costs, size, risk, structure and product mix and which should, in theory, stem from the cost and revenue functions underlying the Panzar-Rosse H-statistics. The bank specific control variables include: lnEQAST which is the ratio of total equity to total assets; lnAST is total assets; lnLOANAST is the ratio of total loans to total assets; $\operatorname{lnDEP}$ is the ratio of total deposit over total deposits and money market funding; lnOBSAST is equal OBS activities over total assets. All variables are in logarithmic form. 
As mentioned earlier, the H-statistics measures the sum of the elasticities of banks' total revenue with respect to input prices. ${ }^{1}$ Hence, it is calculated as the sum of the input prices coefficients $\beta_{1}$ to $\beta_{3}$ as shown in equation (3):

$$
H=\sum_{j=1}^{J} \beta_{j}
$$

where $j=1, \ldots J$, and $J$ is the number of inputs included in the calculations. The Panzar-Rosse Hstatistics is interpreted as follows: $H$ is equal to zero or negative when the competitive structure is a monopoly or a perfectly colluding oligopoly. When $\mathrm{H}$ is equal to 1 , it indicates perfect competition and $0<\mathrm{H}<1$ indicates monopolistic competition. $H$ can be interpreted as a continuous measure of the level of competition, in particular between 0 and 1 , in the sense that higher values of $H$ indicate stronger competition than lower values (see e.g. Bikker and Haaf, 2000; Goddard et al. 2001; Casu and Girardone, 2006).

The Lerner index of monopoly power measures the mark-up of bank output prices over the marginal cost of production and can be approximated empirically using the translog functional form with three inputs and a single output: ${ }^{2}$

$$
\begin{aligned}
& \ln T C_{i t}=\alpha_{0}+\alpha_{1} \ln Q_{i t}+\sum_{j=1}^{3} \beta_{j} \ln P_{j}+\frac{1}{2}\left[\delta_{i t} \ln Q_{i t}{ }^{2}+\sum_{j=1}^{3} \sum_{i=1}^{3} \gamma_{i j} \ln P_{j} \ln P_{i}\right]+ \\
& +\sum_{j=1}^{3} \rho_{j} \ln Q_{i t} \ln P_{j}+t_{1} T+\frac{1}{2} t_{11} T^{2}+\theta_{t} T \ln Q_{i t}+\sum_{j=1}^{3} \psi_{t j} T \ln P_{j}+\varepsilon_{i t}
\end{aligned}
$$

where TC is total costs; $Q$ is total assets; $P_{1}$ is the price of labour; $P_{2}$ is the price of deposits and $P_{3}$ is the price of capital; $T$ is a time trend; $\alpha, \beta, \delta, \gamma, \rho, \mathrm{t}, \theta, \psi$ are parameters to be estimated; and $\varepsilon$ is the error term. ${ }^{3}$ The cost function is estimated using a common frontier and allows the derivation of marginal costs $(M C)$ as follows:

\footnotetext{
${ }^{1}$ The model is based on a general banking market model where the equilibrium output and the equilibrium number of banks are determined by profit maximisation at both the bank and the industry level (see for more details on the derivation of the H-statistics Bikker and Haaf, 2002: 2193-2194 and Bikker, 2004:85-86).

${ }^{2}$ For the theoretical derivation of the Lerner index, see e.g. Fernandez de Guevara et al. (2005).

${ }^{3}$ We apply the common restrictions of standard symmetry and homogeneity in prices to the translog functional form.
} 


$$
M C_{i t}=\frac{T C_{i t}}{Q_{i t}}\left(\alpha_{1}+\delta \ln Q_{i t}+\rho_{j} \ln Q_{i t}+\theta_{t} T \ln Q_{i t}+\varepsilon_{i t}\right)
$$

Marginal costs derived from equation (5) are used to calculate the Lerner index:

$$
L E R N E R=\frac{p_{i}-M C_{i t}}{p_{i}}
$$

where $p_{i}$ the price of production output Q total assets and is calculated as total revenue (interest plus non-interest income) divided by total assets. LERNER $=0$ it indicates perfect competition, while $\mathrm{LERNER}=1$ indicates monopoly.

\subsection{Frontier Efficiency Analysis}

The literature on the measurement of efficiency frontiers can be divided in two main streams: parametric techniques, such as the Stochastic Frontier Analysis (SFA) and non-parametric techniques such as Data Envelopment Analysis (DEA).

The standard SFA generates estimates of X-efficiencies for each banking institution along the lines first suggested by Aigner et al. (1977). Specifically, X-efficiency scores are estimated using the Battese and Coelli's (1992) time-varying stochastic frontier approach for panel data with firm effects which are assumed to be distributed as truncated normal random variables and are also permitted to vary systematically with time (see also Battese and Coelli, 1993; and Coelli et al., 1998). The chosen functional form for the cost function is the translog as specified in equation (4) above with the same three inputs, but with two outputs (total loans and total securities) and a time trend. The final specification is as follows:

$$
\begin{aligned}
& \ln T C_{i t}=\alpha_{0}+\sum_{i=1}^{2} \alpha_{1} \ln Q_{i}+\sum_{j=1}^{3} \beta_{j} \ln P_{j}+\frac{1}{2}\left[\sum_{i=1}^{2} \sum_{j=1}^{3} \delta_{i j} \ln Q_{i} \ln Q_{j}+\sum_{j=1}^{3} \sum_{i=1}^{3} \gamma_{i j} \ln P_{j} \ln P_{i}\right]+ \\
& +\sum_{i=1}^{2} \sum_{j=1}^{3} \rho_{i j} \ln Q_{i} \ln P_{j}+t_{1} T+\frac{1}{2} t_{11} T^{2}+\sum_{i=1}^{2} \theta_{t i} T \ln Q_{i}+\sum_{j=1}^{3} \psi_{t j} T \ln P_{j}+\varepsilon_{i t}
\end{aligned}
$$


The single-equation stochastic cost model is represented by $\ln T C_{i t}=\ln T C^{*}\left(Q_{i t}, P_{j t} ; B\right)+\varepsilon_{i t}$ where the variables are defined as above (equation 4, Section 3.1) and $B$ is a vector of unknown parameters to be estimated. Finally $\varepsilon_{i t}$ is a two-components error term that for the $i$-th firm that can be written as follows: $\varepsilon_{i t}=u_{i t}+v_{i t}$ where $v_{i t}$ is a two-sided error term capturing the effects of statistical noise, assumed to be independently and identically normal distributed with zero mean and variance $\sigma_{v}^{2}$ and independent of the $u_{i t}=\left\{u_{i} \exp [-n(t-T)]\right\}$ where $u_{i}$ is a one-sided error term capturing the effects of inefficiency and assumed to be half normally distributed with mean zero and variance $\sigma_{u}^{2} ; n$ is an unknown parameter to be estimated capturing the effect of inefficiency change over time.

On the other hand, DEA is a mathematical linear programming technique developed by Charnes, Cooper and Rhodes in 1978 (CCR) which identifies the efficient frontier from the linear combination of those units/observations that (in a production space) use comparatively less inputs to produce comparatively more outputs. In particular, if $\mathrm{N}$ firms use a vector of inputs to produce a vector of outputs, the input-oriented CCR measure of efficiency of a particular firm is calculated as:

$$
\begin{array}{ll}
\min _{\theta, \lambda} & \theta_{i} \\
\text { s.t. } & \sum_{r=1}^{N} y^{t}{ }_{m r} \lambda^{t}{ }_{r} \geq y^{t}{ }_{m i} \\
& \sum_{r=1}^{N} x^{t}{ }_{k r} \lambda^{t}{ }_{r} \leq \theta_{i} x^{t}{ }_{k i} \\
& \lambda^{t}{ }_{r} \geq 0
\end{array}
$$

where $\theta_{i} \leq 1$ is the scalar efficiency score for the $\mathrm{i}$-th unit. If $\theta_{i}=1$ the $\mathrm{i}$-th firm is efficient as it lies on the frontier, whereas if $\theta_{i}<1$ the firm is inefficient and needs a (1- $\left.\theta_{i}\right)$ reduction in the inputs levels to reach the frontier.

The CCR model assumes constant returns to scale (CRS), which is the optimal scale in the longrun. The additional convexity constraint $\sum \lambda_{i}=1$ can be included in (8) to allow for variable returns to scale (VRS) (see Banker, Charnes and Cooper (1984) or BCC model The BCC model is 
used in this paper since several factors such as imperfect competition and regulatory requirements may cause a unit not to be operating at the optimal scale. ${ }^{4}$

Choosing the appropriate definition of bank output is a relevant issue for research into banks' cost efficiency. The approach to output definition used in this study is a variation of the intermediation approach, which was originally developed by Sealey and Lindley (1977) and posits that total loans and securities are outputs, whereas deposits along with labour and physical capital are inputs. Specifically, the input variable used in this study is Total Costs (Personnel Expenses + Other Administrative Expenses + Interest Paid + Non-Interest Expenses) whereas the output variables capture both the traditional lending activity of banks (total loans) and the growing non-lending activities (other earning assets).

\subsection{Dynamic Panel Data Granger-Type Causality estimation}

Granger testing is a common method of investigating causal relationships (Granger, 1969) by estimating an equation in which y is regressed on lagged values of $y$ and the lagged values of an additional variable $\mathrm{x}$. The null hypothesis is that $\mathrm{x}$ does not Granger-cause $\mathrm{y}$. If one or more of the lagged values of $\mathrm{x}$ is significant, we are able to reject the null hypothesis and we can conclude that $\mathrm{x}$ Granger causes y. Though imperfect, it is a standard and useful tool for evaluating the character of the causal relationship between two variables. The test was originally designed for pairs of lengthy time series; however, econometricians have recently begun to modify Granger tests to incorporate panel dynamics (see for example Arellano and Bond 1991; Holtz-Eakin et al. 1988; Hurlin 2005; and Hurlin and Venet 2001).

In this study, in order to statistically test the Granger causality between efficiency and competition we employ dynamic panel data methods. Specifically we use the 'difference' and 'system' (or 'combined') Generalised Method of Moments (GMM) procedures developed by Holtz-Eakin et al. (1988), Arellano and Bond (1991), Arellano and Bover (1995) and Blundell and Bond (1998). These methods are useful for panels characterised by a relatively low number of years and a large

\footnotetext{
${ }^{4}$ For an introduction to DEA methodology see, among others, Coelli et al. (1998); Thanassoulis (2001); see Thanassoulis (2007) for an extensive review of this literature.
} 
number of cross-sections per year and help deal with possible problems of endogeneity and measurement error.

The single equation to be estimated is an autoregressive-distributed linear specification as follows:

$$
y_{i t}=\alpha_{0}+\sum_{j=1}^{n} \alpha_{j} y_{i(t-j)}+\sum_{j=1}^{n} \beta_{j} x_{i(t-j)}+\theta_{t}+\eta_{i}+v_{i t}
$$

where $y_{i t}$ is the dependent variable, $\alpha_{0}$ is the intercept, $y_{i(t-j)}$ is $j$ th lag of the dependent variable, $x_{i(t-j)}$ is $j$ th lag of an explanatory variable of interest, $\alpha_{j}$ and $\beta_{j}$ are parameters to be estimated, $\theta_{t}$ is a common time effect, $\eta_{i}$ is an individual bank specific effect, and $v_{i t}$ is a disturbance term. Specifically, the following AR(2) model has been found appropriate for this application:

$$
y_{i t}=\alpha_{0}+\alpha_{1} y_{i, t-1}+\alpha_{2} y_{i, t-2}+\beta_{1} x_{i, t-1}+\beta_{2} x_{i, t-2}+\theta_{t}+\eta_{i}+v_{i t}
$$

Since we expect causality to run in either direction, $y_{i t}$ and $x_{i t}$ are represented alternatively by a measure of competition (the Lerner Index of monopoly power) and a measure of bank cost efficiency (estimated using parametric and non-parametric methods). This will allow us to investigate in a six-year dataset for five EU countries whether changes in competition patterns precede (Granger-cause) changes in bank efficiency, and/or vice-versa whether changes in efficiency Granger-cause changes in competition.

We first run pooled OLS and fixed and random effects regressions. The limitations of these models when estimating equations similar to (9) above are well described in e.g. Bond (2002) and Roodman (2006). We then employ the so-called "difference" GMM (DIF-GMM) estimator developed by Arellano and Bond (1991) for the coefficients in equation (10) where the lagged levels of the regressors are instruments for the equation in first differences. The so-called "difference" GMM (DIF-GMM) estimator relies upon the following moment conditions: ${ }^{5}$

\footnotetext{
${ }^{5}$ Arellano and Bond (1991) derive the moment conditions for AR(1) and AR(2) models and recommend using all the available lags dated $t-2$ and earlier in order to obtain an efficient GMM estimator.
} 


$$
\begin{array}{ll}
E\left(y_{i t-s} \Delta v_{i t}\right)=0 & \text { for } s \geq 2 ; t=4, \ldots, T \\
E\left(x_{i t-s} \Delta v_{i t}\right)=0 & \text { for } s \geq 2 ; t=4, \ldots, T
\end{array}
$$

The Arellano and Bond's (1991) DIF-GMM procedure assumes a set of strict restrictions for the model to be valid: serial correlation in the first order errors and no second-order GMM residual serial correlation. Moreover, it recommends the Sargan statistics of overidentifying restrictions (also known as Hensen's J) to tests the validity of the instrumental variables.

Following Arellano and Bover (1995) and Blundell and Bond (1998) we also employ the system GMM (SYS-GMM) estimator that was designed to overcome some of the limitations of the DIFGMM. ${ }^{6}$ The method involves the estimation of a system composed of equations in first differences and equations in levels where the additional internal instruments are both lagged levels and differences of the series (Blundell and Bond, 1998). In order to consider the additional moments as valid instruments for equation (10), the following additional moment conditions must be satisfied:

$$
\begin{array}{ll}
E\left(\Delta y_{i t-2} \Delta v_{i t}\right)=0 & \text { for } t=4, \ldots, T \\
E\left(\Delta x_{i t-2} \Delta v_{i t}\right)=0 & \text { for } t=4, \ldots, T
\end{array}
$$

With the AR(2) model described in equation (10), a Granger causality test can be measured with a joint test of the two lags of efficiency and competition and is distributed as $\chi^{2}$ with two degrees of freedom. The null hypothesis is that the sum of the lagged coefficients is zero: if the probability is less than 0.10 then the null hypothesis that $x$ Granger cause $y$ is not rejected at the $10 \%$ significance level. The sign of the causal relationship is determined by the sum of the jointly significant coefficients. A positive (negative) sum implies that the causal relationship is also positive (negative), that is an increase (decrease) in $x$ in the past increased (decreased) the $y$ in the present. ${ }^{7}$

\footnotetext{
${ }^{6}$ For example, where the series are highly persistent the lagged levels may be weak instruments for first differences (see e.g. Bond, 2002).

7 While the Granger causality test is a useful tool to denote whether a variable is correlated with the lagged values of the other - after controlling for its own lags, some caution should be used in interpreting the results. Among the main limitations of the Granger are that it is contingent on the choice of variables included in the equations and the number of lags. Moreover, if the sample is unbalanced (as in our case) by increasing the number of lags, the number of observations will be reduced significantly and this may affect the consistency of the results.
} 
Moreover we use an incremental Sargan/Hensen test for the validity of the additional moment restrictions described in (12) required by the SYS-GMM as follows: if $S$ is the Sargan statistics obtained under stronger assumptions and $S^{\prime}$ is the Sargan statistics obtained under weaker assumptions, then the difference $S-S^{\prime}$, is asymptotically distributed as $\chi^{2}$.

Finally the estimated models are also subjected to a test that measures the stability over time (or 'long-run effect') of the $x$ over the $y$. The extant literature suggests the use of a test of the restriction $\beta_{1}+\beta_{2}=0$ that should be interpreted as follows: a rejection of the restriction implies that there is evidence for a long-run effect of $x$ on $y$. Else, $y$ will depend on the change in $x$ rather than on his level. $^{8}$

\subsection{Data}

The data on EU commercial banks are derived from BankScope, a global database published by Bureau VanDjick. The data are collected for an unbalanced sample of 2,701 commercial bank observations operating in France, Germany, Italy, Spain and the United Kingdom between 2000 and 2005. We restricted the analysis to commercial banks as there are still significant differences in the retail market structure among countries and in some countries the saving banking sector is still partially benefiting from state help ${ }^{9}$. The choice of an unbalanced panel is justified mainly to account for mergers and acquisitions during the period. We use data from consolidated accounts, where available, to avoid double-counting. As a result, the banking market for country $\mathrm{X}$ is the defined as the hypothetical market where banks from country X operate and not the national borders of a country (see Bikker and Haaf, 2002). The data were analysed for inconsistencies, reporting errors, missing values and outliers. The final sample is shown in Table 1, which lists the total and average number of banks in the sample by country and year as well as the total average assets over the period.

\section{$<$ Insert Table 1 around here $>$}

\footnotetext{
${ }^{8}$ For more details on this test see Bond and Windmeijer (2005).

${ }^{9}$ For example, until 2005 the German Landesbanks benefited state guarantees have secured the high ratings and have given them access to cheap funding.
} 
It is interesting to note that Italian commercial banks have an average size that is roughly half that of the French, German and Spanish ones. Moreover, UK commercial banks have an average size of almost five times that of Italian banks. The number of banks in the sample is decreasing over time (with the exception of Italy) as the banking sector consolidates further.

\section{Empirical results}

\subsection{Competition Patterns in European Banking}

Table 2 shows the means of the structural indicators of market concentration across our sample of EU countries over the period 2000-2005. The Herfindahl-Hirshman Index (HH) represents the market share (in terms of total assets, total loans and total deposits) of every firm in the market whereas the CR-5 indicates the market share of the five largest firms in the market. We also calculated the $\mathrm{HH}$ for the sub-sample of commercial banks on Total Loans, Total Deposits as well as Total Assets.

The data show that national conditions still vary considerably across countries and this is reflected in the different market structures of the retail banking industry in general and of the commercial banking industry in particular. Against the EU average (in 2005, HH was 601 and CR-5 was 43\% for the EU-25), concentration levels remain relatively low in Germany, Italy and the UK. Most countries, however, show an increase in concentration during the period of analysis. In the UK alone, in the six years period from 2000 concentration (measured as the market share of the five largest banks) increased by $28.57 \%$. Looking at the separate information for commercial banks, they seem to operate in more concentrated markets and this might be also reflected in their measure for market power.

\section{$<$ Insert Table 2 around here $>$}

Figure 1 shows the evolution of marginal costs and of the Lerner index of monopoly power over the sample period and country differences are also apparent. The banking sector in the UK and Germany seem to enjoy the highest relative margin and Spain the lowest. These results are broadly in line with those of Fernandez de Guevara and Maudos (2005). 
$<$ Insert Figure 1 around here $>$

Marginal costs decreased in all countries (with the exception of France) over the sample period, showing an increase in 2005. Italy and Spain, which display the highest average marginal costs, also display the biggest decrease, possibly because of the reduction of both financial costs and operating costs. Despite the decrease in marginal costs, Italy and Spain also display the highest increase in the Lerner Index, thus indicating that the decrease in marginal cost was smaller than the increase in the average price of assets. On the other hand, the Lerner Index decreases over the period in France and in the UK. Comparing our results with averages for the whole banking system (see Fernandez de Guevara and Maudos, 2005), they confirm that, despite being more concentrated, commercial banks enjoy a lower market power compared to saving banks. This reinforces our decision to concentrate this analysis on the commercial banking sector because of the potential distortions still existing in the EU saving banking sector.

\subsection{Competition Patterns in European Banking: H-statistic}

Following the empirical literature on competition in banking markets, we estimated the reduced form revenue equation specified in (2) using a panel data framework. The regression models are estimated using the fixed effect estimators. Estimations are carried out at each individual country level.

$<$ Insert Table 3 around here $>$

Table 3 reports the regression results. The estimated H-statistic indicates monopolistic competition in all countries and ranges from 0.3715 in France to 0.7783 in Germany. As mentioned in Section 3.1, under the assumption of constant elasticity of demand across markets, the model specification is consistent with a continuous interpretation of $\mathrm{H}$ and thus the comparison between countries is acceptable. Therefore, competition in the commercial banking sector seems the highest in Germany, Spain and the UK, followed by Italy and Spain. These results are consistent with the current literature, which finds the monopolistic competition the prevalent market structure in European 
countries $^{10}$ (see among others, Molyneux et al., 1994; De Bandt and Davies, 2000; Bikker and Haaf, 2002, Claessen and Laeven, 2004, Casu and Girardone, 2005). An analysis of the sign and significance of the regression coefficients (Table 3) indicates that both the price of funds and the price of labour are always positive and statistically significant for all countries in the sample. The impact of the cost of capital seems to be minimal compared to the other input prices (with the exception of UK and Germany). These results are again consistent with previous studies, which find that the impact of the capital factor input price varies by countries and it is the least important component of H (Molyneux et al., 1994; Bikker and Haaf, 2002). This might be due to the poor quality of capital expenses and fixed assets data. The variable TA (Total assets), which controls for the size of the bank and can be considered a proxy for scale economies, is also positive and statistically significant in all countries. The majority of the other bank-specific variables report mixed results.

To validate our results, we conducted the equilibrium test for all the banking markets and found that the banking systems are in long-run equilibrium ${ }^{11}$.

\section{The evolution of bank efficiency: SFA and DEA analysis}

The yearly SFA and DEA results for the countries in our sample, as well as the average efficiency over the period are shown in Table 4.

The average overall efficiency score for the five EU banking industries over the whole sample period is $75.43 \%$ for SFA and $71.23 \%$ for DEA, thus indicating a $24.57 \%$ and $28.77 \%$ respectively average potential reduction in inputs utilisation. The results for the different EU countries in 2005 vary between $74.51 \%$ in Germany and $62.04 \%$ in Italy in the DEA estimations and between $80.47 \%$ in Italy and $68.88 \%$ in Spain for the SFA estimations.

\section{$<$ Insert Table 4 around here $>$}

\footnotetext{
${ }^{10}$ F-Test results indicate that the both hypothesis $\mathrm{H}$-stat $=0$ (monopoly) and the hypothesis $\mathrm{H}$-stat $=1$ (perfect competition) are rejected in all countries. Therefore the hypothesis of $1<\mathrm{H}<1$ (monopolistic competition) holds in countries.

${ }^{11}$ The equilibrium test can be performed by recalculating the Panzar and Rosse's H-statistics replacing the dependent variable total revenue over assets with the natural log of return on assets (which is equal to net income over total assets), as shown in equation (2). The findings will be interpreted as follows: $\mathrm{H}<0$ would indicate disequilibrium and $\mathrm{H}=0$ would indicate equilibrium (see Shaffer, 1982; Molyneux et al., 1994; Claessens and Laeven, 2004).
} 
Both methodologies indicate and average inefficiency scores of about $30 \%$, a result that is broadly in line with the main literature on bank efficiency (see Goddard et al., 2007). Differently from most studies analysing bank efficiency during the 1990s, which find improvements in resources utilisation, the yearly results seem to indicate, for most countries, an increase in input wastage from 2000-2001 onwards (see Figure 2). This trend could be explained by the initial effort towards cutting costs fostered by deregulation and increased competition; the wave of mergers and acquisitions that followed might have imposed higher costs on banks, thereby decreasing their cost efficiency. However, decreases in bank efficiency can also be a signal that banks are struggling under excessive competition, with serious implications for the sector stability, or that they are reacting to competition by increased market power.

$<$ Insert Figure 2 around here $>$

The analysis so far has highlighted that the main EU banking markets are becoming progressively more concentrated and less efficient. Furthermore, different measures of competition do not exclusively indicate an overall increase of competitive pressure over the period.

The next section will investigate the relationship between efficiency and competition; particularly we study the direction of the causal relationship (if any) between the two variables.

\subsection{The Relationship and Causality between Competition and Efficiency}

Tables 5 and 6 report the results of our empirical analysis on the relationship and causality between competition and efficiency. These are derived from the estimation of cross-sectional pooled OLS regression models, fixed and random effects panels, the DIF-GMM robust estimators and the twostep robust SYS-GMM model. Our specifications include two lags of the dependent and explanatory variables and they are carried out twice using as alternative measures of cost efficiency the parametric SFA and the non-parametric DEA (results are reported in panels (a) and (b) respectively).

$<$ Insert Table 5 around here $>$

In the first set of estimations we test the causality from efficiency to competition (Table 5). Competition, measured as the Lerner index of monopoly power, is estimated as a function of lagged competition and lagged cost efficiency. Looking at the results, the first and second lags of 
competition are usually significantly different from zero at the one per cent level in both panels (a) and (b). This indicates that competition at time $t$ is influenced by previous years' competition. Granger causality is assessed as the joint test of the two lags of efficiency on competition as follows: $\beta_{1}=\beta_{2}=0$. A p-value $<0.10$ rejects at the $10 \%$ significance level the null hypothesis that efficiency does not Granger-cause competition. However, following Arellano and Bond (1991), three additional conditions should be satisfied for the Granger causality to be statistically valid: a significant AR(1) serial correlation, lack of AR(2) serial correlation and a high Sargan/Hensen test statistics: a low p-value $(<0.10)$ for this statistics indicates that the model is mispecified. Our findings in Table 5 suggest that in the majority of cases the Granger coefficient is negative, thereby indicating that cost efficiency negatively Granger-causes competition (i.e. an increase in bank efficiency Granger-causes a decrease in competition). The Granger coefficient is significant and the three additional conditions above are satisfied in at least three cases, particularly when lagged SFA efficiency measures are included as explanatory variables. The Granger causality test rejects the null of non-causality in the case of OLS estimation, random effects and two-step robust GMM estimators. Finally the long-run effect is significant only in one case in panel (b) therefore it is not possible to infer on the stability of the relationship between competition and efficiency over the long period.

Table 6 shows the results for the causality running from competition to efficiency. The significance of the coefficients for the first and second lags of efficiency seem to suggest that efficiency is affected significantly by previous years' efficiency (and in some cases the inefficiency as noted by the negative and significant sign of the second lag in panel a). Overall, the results seem to suggest that the Granger causality running from competition to efficiency is relatively weak. However, where significant, the sign of the Granger coefficient is positive.

\section{$<$ Insert Table 6 around here $>$}

Overall, our results seem to provide some empirical evidence to support the existence of a cost efficiency-to-competition negative causation for our sample of European commercial banks. In other words, higher cost efficiency seems to cause a decrease in competition. This is consistent with the hypothesis that more efficient banks are in a position to exploit market power and therefore there seem to be a trade-off between efficiency and competition. On the other hand it seems that the effect of competition on efficiency is less clear. These results seem to be consistent with the 
"efficient structure hypothesis" whereby the best managed firms have the lowest costs and the largest market shares, which in turns leads to a higher degree of concentration. It seems therefore that efficiency determines competition, with a negative causality, whereas competition might stimulate managers to become more efficient, but the causality, although positive, is weak.

\section{Conclusions}

Competition is generally considered as a positive force, often associated with increased efficiency and enhanced consumers' welfare. However, in the banking sector it is a more controversial issue as regulators have historically been mindful of the trade-off between competition and stability. The acceleration in the recent consolidation process, however, is raising concerns about increased concentration in the banking sector and its potential implications for public policy deriving from increased market power in the banking sector. Policymakers are faced with the contrasting issues as to whether competitive forces are posing a threat for the sector stability or whether the consolidation wave poses a threat to competition in the sector. Using bank level balance sheet data for the major EU commercial banking markets, this paper aims to shed some light on the second issue by investigating the relationship between alternative measures of competition, concentration and bank-specific efficiency levels. Furthermore we use a dynamic panel data Granger causality test to investigate the dynamics of the relationship between competition and efficiency. Our findings suggest a negative causation between efficiency and competition, whereas the causality running from competition to efficiency, although positive, is relatively weak. These results pose further questions for competition policies. Recent decreases in bank efficiency could either be a signal that banks are struggling under excessive competition, with serious implications for the sector stability, or that they are reacting to competition by increased market power. The latter might seem a more likely explanation. However, as Vives (2001) pointed out, market power could be beneficial in banking as it provides incentives for banks to undertake less risky strategies. 


\section{References}

Aigner, D.J., Lovell C.A.K. and P. Schmidt. "Formulation and Estimation of Stochastic Frontier Production Function Models". Journal of Econometrics, 1977, 6, 21-37.

Amel D., Barnes, C., Panetta, F., and C. Salleo. "Consolidation and Efficiency in the Financial Sector: a Review of the International Evidence” Journal of Banking and Finance, 2004, 28, 2493-2519.

Arellano, M. and S.R. Bond, "Some Tests of Specification for Panel Data: Monte Carlo Evidence and An Application to Employment Equations". Review of Economic Studies, 1991, 58, 277 297.

Arellano, M., and O. Bover. "Another Look at the Instrumental Variables Estimation of Error Components Models". Journal of Econometrics, 1995, 68 29-51.

Bain, J.S."Relation of Profit Rate to Industry Concentration", Quarterly Journal of Economics, 1951, 65, August, 293-324.

Banker, R. D., Charnes, A., Cooper, W.W. "Some models for the estimating technical and scale inefficiency in Data Envelopment Analysis”. Management Science, 1984, 30, 1078-92.

Battese, G.E. and T.J. Coelli. "Frontier Production Functions, Technical Efficiency and Panel Data: With Application to Paddy Farmers in India”. Journal of Productivity Analysis, 1992, 3, 153-169.

Battese, G.E. and T.J. Coelli. “A Stochastic Frontier Production Function Incorporating a Model for Technical Inefficiency Effects". Working Paper in Econometrics and Applied Statistics, Department of Econometrics, University of New England, Armidale, 1993, 69.

Baumol, W. J., Panzar J. C. and R.D. Willig. Contestable Markets and the Theory of Industry Structure. (San Diego, 1982) Harcourt Brace Jovanovich.

Berger, A.N. "The Profit-Structure Relationship in Banking - Tests of Market-Power and Efficient-Structure Hypotheses" Journal of Money, Credit, and Banking, 1995, 27, 404-31.

Berger, A.N., Demirgüç-Kunt A., Levine R. and J.G. Haubrich "Bank Concentration and Competition: An Evolution in the Making”, Journal of Money, Credit and Banking, 2004, 36, Part 2, 433-453.

Berger A. N. and D.B. Humphrey, Megamergers in Banking and the Use of Cost Efficiency as an Antitrust Defense, Antitrust Bulletin, 1992, 37, Fall, 541-600.

Berger A. N. and D.B. Humphrey. "Efficiency of Financial Institutions: International Survey and Directions for Future Research”. European Journal of Operational Research, 1997, 98, 175 212. 
Bikker, J.A., Competition and Efficiency in a Unified European Banking Market, 2004, Edward Elgar Publishing Limited.

Bikker, J.A. and Haaf, K. "Measures of competition and concentration in the banking industry: A review of the literature". De Nederlandsche Bank, Research Series Supervision, 2000, No.27, September.

Bikker, J.A. and K. Haaf "Competition, Concentration and Their Relationship: An empirical Analysis of the Banking Industry", Journal of Banking and Finance, 2002, 26, 2191-2214.

Blundell, R. and S.R. Bond. "Initial Conditions and Moment Restrictions in Dynamic Panel Data Models", Journal of Econometrics, 1998, 87, 115-43.

Bond, S.R. "Dynamic Panel Data Models: A Guide to Micro Data Methods and Practice", Portuguese Economic Journal, 2002, 1, 141-162.

Bond, S.R. and F. Windmeijer. "Reliable Inference for GMM Estimators? Finite Sample Properties of Alternative Test Procedures in Linear Panel Datamodels," Econometric Reviews, 2005, 24(1), 1-37.

Bresnahan, T.F. "Empirical Studies of Industries with Market Power”, In: Schmalensee, R., Willig, R.D. (Eds.), Handbook of Industrial Organisation, 1989, vol. II. Elsevier, Amsterdam, 10121055 .

Casu B. and C. Girardone. 'Bank Competition, Concentration and Efficiency in the Single European Market' The Manchester School, 2006, 74 (4), 441- 468.

Charnes, A., Cooper, W.W. and E. Rhodes "Measuring Efficiency of Decision Making Units", European Journal of Operational Research, 1978, 2, 429-44.

Claessens, S. and L. Laeven. "What Drives Bank Competition? Some International Evidence". Journal of Money, Credit, and Banking, 2004, 36, Part 2, 563-584.

Coelli, T.J., Prasada Rao D.S. and G. Battese, An Introduction to Efficiency and Productivity Analysis. (Norwell, 1998) Kluwer Academic Publishers.

De Bandt, O. and E.P. Davis "Competition, Contestability and Market Structure in European Banking Sectors on the Eve of EMU", Journal of Banking and Finance, 2000, 24, 10451066

Demsetz H., "Two Systems of Belief about Monopoly", in Goldschmid H.J., Mann H.M. and J.F. Weston (eds), Industrial Concentration: The New Learning, 1974, 164-184, Boston: Little Brown.

Demirgüç-Kunt A. and R. Levine, "Bank Concentration: Cross-Country Evidence”, 2000, World Bank, Mimeo, October. 
European Central Bank “EU Banking Structures” October 2006.

European Commission "White Paper on Financial Services Policy (2005-2010)". (SEC(2005) 1574).

Evanoff D.D. and D.L. Fortier "Re-evaluation of the Structure-Conduct-Performance Paradigm in Banking”, Journal of Financial Services Research, 1988, 1, 277-294.

Fernandez de Guevara J., Maudos J. and F. Perez. "Market Power in European Banking Sector". Journal of Financial Services Research, 2005, 27:2, 109-137.

Goddard, J.A., Molyneux, P. and J.O.S. Wilson. "European Banking. Efficiency, Technology and Growth". (John Wiley and Sons, 2001), England.

Goddard, J.A., Molyneux, P., Wilson J.O.S. and M. Tavakoli. "European Banking: An Overview". Journal of Banking and Finance, 2007, 31, 1911-1935.

Greene, W.H. Econometric Analysis, 2003, Prentice Hall, 5th Edition.

Granger, Clive W.J. "Investigating Causal Relations by Econometric Models and Cross-Spectral Methods." Econometrica, 1969, 37:424-438.

Grillo M. "Concorrenza e Concentrazioni nel Sistema Bancario". Associazione per lo sviluppo degli studi di banca e borsa, Universita' Cattolica del Sacro Cuore, 2005, Quaderno 225, Milano.

Hicks, J. “The Theory of Monopoly”, Econometrica, 1935, 3, 1-20.

Holtz-Eakin, D., W. Newey and H.S. Rosen. Estimating Vector Autoregressions with Panel Data". Econometrica, 1988, 56, 1371-95.

Hurlin, Christophe. "Testing for Granger Causality in Heterogeneous Panel Data Models" [English Title]. Revue Economique 2005, 56:1-11.

Hurlin, Christophe and Baptiste Venet. “Granger Causality Tests in Panel Data Models with Fixed Coefficients.” Working Paper Eurisco 2001-09, University of Paris Dauphine.

Iwata G. "Measurement of Conjectural Variations in Oligopoly". Econometrica, 1974, 42 (5), 947966.

Lau L.J. "On Identifying the Degree of Competitiveness from Industry Price and Output Data", Economics Letters, 1982, 10, 93-99.

Lerner A.P. "The Concept of Monopoly and the Measurement of Monopoly Power" Review of Economic Studies, 1934, 1(3) 157-175.

Liebenstein, H. "Allocative Efficiency Versus X-Efficiency”, American Economic Review, 1966, Vol. 56, pp. 392-415.

Molyneux, P., Lloyd-Williams D.M. and J. Thornton "Competitive Conditions in European banking”, Journal of Banking and Finance, 1994, 18, 445-459. 
Mueller, D.C. "The Persistence of Profits above the Norm”. Economica, 1977, 44, 369-380.

Mueller, D.C. "Profits in the Long Run” Cambridge University Press, 1986, Cambridge, UK.

Panzar, J.C. and J.N. Rosse "Testing for Monopoly Equilibrium", Journal of Industrial Economics, $1987,35,443-456$.

Pilloff, S.J. "Performance Changes and Shareholder Wealth Creation Associated with Mergers of Publicly Traded Banking Institutions", Journal of Money, Credit and Banking, 1996, 28, 294-310.

PriceWaterhouseCoopers. European Banking Consolidation. April 2006.

Roodman D. "How To Do xtabond2: An Introduction to 'Difference' and 'System' GMM in Stata", Center for Global Development, Working Paper, 2006, 103, December.

Rosse, J.N. and J.C. Panzar "Chamberlin vs Robinson: An Empirical Study for Monopoly Rents". 1977. Bell Laboratories Economic Discussion Paper.

Sealey, C. and J.T. Lindley "Inputs, Outputs and a Theory of Production and Cost at Depositary Financial Institutions", Journal of Finance, 1977, 32, 1251-1266.

Shaffer, S. "Non-Structural Test for Competition in Financial Markets" In: Bank Structure and Competition, Conference Proceedings, 1982, Federal Reserve Bank of Chicago, 225-3.

Smirlock M. "Evidence on the (Non) Relationship Between Concentration and Profitability", Journal of Money, Credit and Banking, 1958, 17, 1, 69-83.

Thanassoulis, E. Introduction to the Theory and Application of Data Envelopment Analysis. A Foundation Text with Integrated Software, 2001, USA, Kluwer Academic Publishers.

Thanassoulis, E., Portela M.C.S. and O. Despic "DEA - The Mathematical Programming Approach to Efficiency Analysis" in The Measurement of Productive Efficiency and Productivity Growth. 2007, Edited By H. O. Fried; C. A. K. Lovell, S.S. Schmidt. Oxford University Press.

Vives X. "Competition in the Changing World of Banking" Oxford Review of Economic Policy, 2001, 17 (4), $535-547$.

Walkner, C., J.P. Raes. "Integration and Consolidation in EU Banking - An Unfinished Business" European Commission - DG Economics and Financial Affairs, Economic Papers 226, 2005, April.

Weill L. "On the Relationship between Competition and Efficiency in the EU Banking Sector", Kredit und Kapital, 2004, 37, 3, 329-352.

Windmeijer, F. "A Finite Sample Correction for the Variance of Linear Efficient Two-Step GMM Estimators". Journal of Econometrics, 2005, 126(1), 25-51. 
Table 1

Total Average Size of Sampled Banks and Number of Institutions

\begin{tabular}{c|cccccr}
\hline & France & Germany & Italy & Spain & UK & Total by year \\
\hline 2000 & 101 & 111 & 121 & 52 & 76 & 461 \\
2001 & 105 & 107 & 130 & 56 & 70 & 468 \\
2002 & 99 & 104 & 125 & 52 & 72 & 452 \\
2003 & 93 & 104 & 144 & 47 & 78 & 466 \\
2004 & 86 & 96 & 142 & 46 & 77 & 447 \\
2005 & 77 & 89 & 135 & 39 & 67 & 407 \\
Total number of banks & 561 & 611 & 797 & 292 & 440 & 2,701 \\
Total assets by country & & & & & & \\
over the period (mil $€$ ) & $22,708.0$ & $24,657.5$ & $11,690.6$ & $22,938.6$ & $49,947.2$ & \\
\hline
\end{tabular}


Table 2

Concentration Measures: Herfindahl-Hischman Index (HH) and CR-5

\begin{tabular}{|c|c|c|c|c|c|c|c|}
\hline & 2000 & 2001 & 2002 & 2003 & 2004 & 2005 & 2000-2005 \\
\hline \multicolumn{8}{|c|}{$\begin{array}{l}\text { HH Total Loans } \\
\text { (Commercial banks) }\end{array}$} \\
\hline France & 1373 & 1443 & 1282 & 1271 & 849 & 1371 & $-0.14 \%$ \\
\hline Germany & 1928 & 1956 & 1764 & 1635 & 2164 & 2010 & $4.27 \%$ \\
\hline Italy & 987 & 872 & 945 & 646 & 564 & 1137 & $15.22 \%$ \\
\hline Spain & 1890 & 2112 & 1606 & 2650 & 2309 & 3064 & $62.15 \%$ \\
\hline UK & 924 & 917 & 1027 & 1085 & 1122 & 1084 & $17.29 \%$ \\
\hline \multicolumn{8}{|c|}{ HH Total Deposits (Commercial Banks) } \\
\hline France & 1374 & 1704 & 1427 & 1470 & 1417 & 1682 & $22.42 \%$ \\
\hline Germany & 1872 & 1827 & 1774 & 1953 & 2781 & 2826 & $50.97 \%$ \\
\hline Italy & 1138 & 992 & 974 & 742 & 730 & 1439 & $26.50 \%$ \\
\hline Spain & 2016 & 2321 & 1713 & 2870 & 2328 & 3326 & $64.95 \%$ \\
\hline UK & 935 & 955 & 1066 & 1116 & 1131 & 1327 & $41.88 \%$ \\
\hline \multicolumn{8}{|c|}{$\begin{array}{l}\text { HH Total Assets } \\
\text { (Commercial Banks) }\end{array}$} \\
\hline France & 1511 & 1957 & 1603 & 1669 & 1386 & 1622 & $7.34 \%$ \\
\hline Germany & 1944 & 1933 & 1814 & 2019 & 2776 & 2833 & $45.72 \%$ \\
\hline Italy & 1038 & 915 & 977 & 707 & 675 & 1315 & $26.71 \%$ \\
\hline Spain & 2096 & 2466 & 1824 & 2992 & 2481 & 3459 & $65.02 \%$ \\
\hline UK & 940 & 952 & 1080 & 1139 & 1164 & 1293 & $37.65 \%$ \\
\hline \multicolumn{8}{|c|}{$\begin{array}{l}\text { HH Total Assets } \\
\text { (Banking Sector) }\end{array}$} \\
\hline France & 587 & 606 & 551 & 597 & 623 & 758 & $29.13 \%$ \\
\hline Germany & 151 & 158 & 163 & 173 & 178 & 174 & $15.23 \%$ \\
\hline Italy & 190 & 260 & 270 & 240 & 230 & 230 & $21.05 \%$ \\
\hline Spain & 581 & 532 & 513 & 506 & 482 & 487 & $-16.18 \%$ \\
\hline UK & 264 & 282 & 307 & 347 & 376 & 399 & $51.14 \%$ \\
\hline \multicolumn{8}{|c|}{$\begin{array}{l}\text { CR-5 } \\
\text { (Banking Sector) }\end{array}$} \\
\hline France & 47 & 47 & 45 & 47 & 50 & 53 & $12.77 \%$ \\
\hline Germany & 20 & 20 & 21 & 22 & 22 & 22 & $10.00 \%$ \\
\hline Italy & 23 & 29 & 31 & 28 & 26 & 27 & $17.39 \%$ \\
\hline Spain & 46 & 44 & 44 & 43 & 42 & 42 & $-8.70 \%$ \\
\hline UK & 28 & 29 & 30 & 33 & 35 & 36 & $28.57 \%$ \\
\hline
\end{tabular}

Source: Authors' calculations and ECB (2006). 
Table 3

H Statistics Results ${ }^{\mathrm{a}, \mathrm{b}, \mathrm{c}}$

\begin{tabular}{|c|c|c|c|c|c|}
\hline Variables & FRANCE & GERMANY & ITALY & SPAIN & UK \\
\hline P1 & $\begin{array}{c}\mathbf{0 . 0 8 5 4 * *} \\
(0.0274)\end{array}$ & $\begin{array}{c}\mathbf{0 . 3 2 2 2} * * * \\
(0.0353)\end{array}$ & $\begin{array}{c}\mathbf{0 . 2 6 6 8 * * *} \\
(0.0234)\end{array}$ & $\begin{array}{c}\mathbf{0 . 3 7 1 4} * * * \\
(0.0434)\end{array}$ & $\begin{array}{r}\mathbf{0 . 2 5 6 3} * * * \\
(0.0339)\end{array}$ \\
\hline $\mathbf{P 2}$ & $\begin{array}{c}\mathbf{0 . 2 8 5 1} * * * \\
(0.0171)\end{array}$ & $\begin{array}{c}\mathbf{0 . 4 1 4 2} * * * \\
(0.0189)\end{array}$ & $\begin{array}{c}\mathbf{0 . 2 8 5 8} * * * \\
(-0.0120)\end{array}$ & $\begin{array}{c}\mathbf{0 . 3 4 3 8} * * * \\
(-0.0239)\end{array}$ & $\begin{array}{c}\mathbf{0 . 4 5 2 1} \text { **** } \\
(0.0166)\end{array}$ \\
\hline P3 & $\begin{array}{c}\mathbf{0 . 0 0 1 1} \\
(0.0169)\end{array}$ & $\begin{array}{c}\mathbf{0 . 0 4 1 8} * * \\
(0.0122)\end{array}$ & $\begin{array}{c}-\mathbf{0 . 0 1 3 1} \\
(-0.0071)\end{array}$ & $\begin{array}{c}\mathbf{0 . 0 2 0 7} \\
(-0.0236)\end{array}$ & $\begin{array}{c}\mathbf{0 . 0 3 4 9} * * \\
(0.0110)\end{array}$ \\
\hline EQAST & $\begin{array}{l}-\mathbf{0 . 0 8 4 6 *} \\
(0.0336)\end{array}$ & $\begin{array}{l}\mathbf{0 . 0 5 7 0 *} \\
(0.0261)\end{array}$ & $\begin{array}{c}\mathbf{0 . 0 7 2 3} * * \\
(0.0249)\end{array}$ & $\begin{array}{c}\mathbf{- 0 . 1 3 4 0} * * * \\
(0.0348)\end{array}$ & $\begin{array}{c}\mathbf{0 . 1 1 9 4} * * \\
(0.0364)\end{array}$ \\
\hline TA & $\begin{array}{c}\mathbf{0 . 7 5 6 9} * * * \\
(0.0341)\end{array}$ & $\begin{array}{c}1.0558 * * * \\
(0.0291)\end{array}$ & $\begin{array}{c}\mathbf{0 . 8 5 9 9} * * * \\
(0.0204)\end{array}$ & $\begin{array}{c}\mathbf{0 . 8 9 7 9} * * * \\
(-0.0427)\end{array}$ & $\begin{array}{c}1.0197 * * * \\
(-0.0298)\end{array}$ \\
\hline LOANAST & $\begin{array}{l}-\mathbf{0 . 0 0 8 5} \\
(0.0252)\end{array}$ & $\begin{array}{c}\mathbf{0 . 0 8 0 0} * * * \\
(0.0176)\end{array}$ & $\begin{array}{c}\text { 0.0382* } \\
(-0.0171)\end{array}$ & $\begin{array}{c}\mathbf{0 . 0 2 4 8} \\
(-0.0340)\end{array}$ & $\begin{array}{c}\mathbf{0 . 0 2 1 9} \\
(-0.0191)\end{array}$ \\
\hline DEPOS & $\begin{array}{c}\mathbf{0 . 0 6 9 1} \\
(-0.1125)\end{array}$ & $\begin{array}{c}\mathbf{0 . 1 9 6 8} \\
(-0.3363)\end{array}$ & $\begin{array}{c}\mathbf{0 . 0 3 8 4} \\
(-0.1014)\end{array}$ & $\begin{array}{c}\mathbf{0 . 4 0 8 3} \\
(-0.4906)\end{array}$ & $\begin{array}{l}-\mathbf{0 . 3 3 5 4} * \\
(-0.1382)\end{array}$ \\
\hline $\begin{array}{l}\text { OBSTA } \\
\text { CONS }\end{array}$ & $\begin{array}{c}\mathbf{0 . 0 1 1 4} \\
(-0.0150) \\
\mathbf{0 . 0 3 0 9} \\
(-0.2045)\end{array}$ & $\begin{array}{c}\mathbf{0 . 0 0 4 3} \\
(-0.0015) \\
-\mathbf{0 . 0 2 0 2} \\
(-0.1403)\end{array}$ & $\begin{array}{c}\mathbf{- 0 . 0 1 2 0} \\
(-0.0080) \\
\mathbf{0 . 6 0 9 5 * * *} \\
(0.1118)\end{array}$ & $\begin{array}{c}-\mathbf{0 . 0 0 3 3} \\
(-0.0101) \\
\mathbf{0 . 5 6 5 2} \\
(-0.2251)\end{array}$ & $\begin{array}{c}\mathbf{0 . 0 0 0 3} \\
(-0.0083) \\
\mathbf{0 . 7 3 0 7} \\
(-0.1845)\end{array}$ \\
\hline H statistic & $0.3715 * * *$ & $0.7783 * * *$ & $0.5395 * * *$ & $0.7359 * * *$ & 0.7433 \\
\hline $\begin{array}{c}\text { F test } \\
(\text { Hstat }=0)\end{array}$ & 119.14 & 331.25 & 389.33 & 197.35 & 355.90 \\
\hline Prob $>$ F & 0.0000 & 0.0000 & 0.0000 & 0.0000 & 0.0000 \\
\hline $\begin{array}{c}\text { F test } \\
(\text { Hstat }=1)\end{array}$ & 340.96 & 26.89 & 283.56 & 25.43 & 42.43 \\
\hline Prob $>F$ & 0.0000 & 0.0000 & 0.0000 & 0.0000 & 0.0000 \\
\hline $\begin{array}{l}\text { Market in } \\
\text { equilibrium }\end{array}$ & Yes & Yes & Yes & Yes & Yes \\
\hline
\end{tabular}

${ }^{\mathrm{a}}$ Standard errors in brackets.

${ }^{\mathrm{b}} \mathrm{P} 1$ = average cost of labour, $\mathrm{P} 2=$ average cost of deposits, $\mathrm{P} 3=$ average cost of capital, EQAST= equity/assets, $\mathrm{TA}=$ total assets, LOANAST $=$ loans/assets, DEPOS $=$ deposits/deposits + money market funding, OBSTA $=$ OBS activities/assets, $\mathrm{CONS}=$ constant term.

With the exception of factor prices all variables are expressed in logs.

$\mathrm{c} * \mathrm{p}<0.05 ; * * \mathrm{p}<0.01 ; * * * \mathrm{p}<0.001$ 
Table 4

DEA and SFA Efficiency Scores by Year and Country

\begin{tabular}{|c|c|c|c|c|c|c|c|c|}
\hline & Countries & 2000 & 2001 & 2002 & 2003 & 2004 & 2005 & 2000- 2005 \\
\hline \multirow{6}{*}{$\begin{array}{c}\text { DEA } \\
\text { Efficiency } \\
\text { Scores }\end{array}$} & France & 69.46 & 67.29 & 65.59 & 65.57 & 3.69 & 62.39 & $-10.17 \%$ \\
\hline & Germany & 72.29 & 73.33 & 69.45 & 68.73 & 70.50 & 74.51 & $3.07 \%$ \\
\hline & Italy & 76.33 & 83.71 & 65.31 & 63.81 & 77.49 & 62.04 & $-18.72 \%$ \\
\hline & Spain & 84.67 & 80.11 & 79.47 & 72.20 & 7520 & 78.64 & $-7.13 \%$ \\
\hline & UK & 72.12 & 76.28 & 62.78 & 69.62 & 66.71 & 67.63 & $-6.23 \%$ \\
\hline & Average & 74.97 & 76.14 & 68.52 & 67.98 & 70.12 & 69.04 & $-7.91 \%$ \\
\hline \multirow{6}{*}{$\begin{array}{c}\text { SFA } \\
\text { Efficiency } \\
\text { Scores }\end{array}$} & France & 74.10 & 73.83 & 71.17 & 71.86 & 70.23 & 69.75 & $-5.87 \%$ \\
\hline & Germany & 74.77 & 74.13 & 73.76 & 72.09 & 71.34 & 70.85 & $-5.25 \%$ \\
\hline & Italy & 84.13 & 83.35 & 81.42 & 81.17 & 80.57 & 80.47 & $-4.35 \%$ \\
\hline & Spain & 75.19 & 73.32 & 71.77 & 72.20 & 71.51 & 68.88 & $-8.40 \%$ \\
\hline & UK & 76.95 & 75.46 & 74.15 & 73.48 & 72.53 & 70.54 & $-8.33 \%$ \\
\hline & Average & 77.03 & 76.02 & 74.45 & 74.16 & 73.23 & 72.10 & $-6.40 \%$ \\
\hline
\end{tabular}


Table 5

Does Cost Efficiency Granger-Cause Competition?

\begin{tabular}{|c|c|c|c|c|c|c|}
\hline $\begin{array}{l}\text { Dependent variable } \\
y= \\
\text { LERNER INDEX }\end{array}$ & Variables and tests & OLS levels & $\begin{array}{l}\text { Fixed } \\
\text { Effects }\end{array}$ & $\begin{array}{l}\text { Random } \\
\text { Effects }\end{array}$ & $\begin{array}{c}\text { DIF-GMM } \\
\text { t-2 } \\
\text { Robust }\end{array}$ & $\begin{array}{c}\text { Two-step } \\
\text { SYS-GMM } \\
\text { Robust }\end{array}$ \\
\hline \multirow[t]{11}{*}{$\begin{array}{l}\text { (a) } x=\text { SFA cost } \\
\text { efficiency }\end{array}$} & LER1 & $\begin{array}{c}.8832 * * * \\
(.0339)\end{array}$ & $\begin{array}{c}.2027 * * * \\
(.0283)\end{array}$ & $\begin{array}{l}.7658 * * * \\
(.0232)\end{array}$ & $\begin{array}{c}.4651^{* * *} \\
(.2002)\end{array}$ & $\begin{array}{c}.7217 * * * \\
(.1437)\end{array}$ \\
\hline & LER2 & $\begin{array}{l}.0602 * \\
(.0324)\end{array}$ & $\begin{array}{c}-.0940 * * * \\
(.0279)\end{array}$ & $\begin{array}{l}.1163 * * * \\
(.0225)\end{array}$ & $\begin{array}{c}.0037 \\
(.0488) \\
\end{array}$ & $\begin{array}{c}.1233 \\
(.1397) \\
\end{array}$ \\
\hline & SFAEFF1 & $\begin{array}{l}.0003 \\
(.0004)\end{array}$ & $\begin{array}{l}-.0016 \\
(.0058)\end{array}$ & $\begin{array}{c}.0002 \\
(.0006)\end{array}$ & $\begin{array}{l}-.0081 \\
(.0067)\end{array}$ & $\begin{array}{l}.0002 \\
(.0005)\end{array}$ \\
\hline & SFAEFF2 & $\begin{array}{l}-.0003 \\
(.0004)\end{array}$ & $\begin{array}{l}.0014 \\
(.0059)\end{array}$ & $\begin{array}{l}-.0002 \\
(.0007)\end{array}$ & $\begin{array}{l}.0079 \\
(.0068)\end{array}$ & $\begin{array}{l}-.0002 \\
(.0005)\end{array}$ \\
\hline & ml p-value & .3485 & $\mathrm{n} / \mathrm{a}$ & $\mathrm{n} / \mathrm{a}$ & .046 & .085 \\
\hline & $\mathrm{m} 2 \mathrm{p}$-value & $\mathrm{n} / \mathrm{a}$ & $\mathrm{n} / \mathrm{a}$ & $\mathrm{n} / \mathrm{a}$ & .956 & .727 \\
\hline & $\begin{array}{l}\text { Sargan/Hensen p- } \\
\text { value }\end{array}$ & $\mathrm{n} / \mathrm{a}$ & $\mathrm{n} / \mathrm{a}$ & $\mathrm{n} / \mathrm{a}$ & .300 & .577 \\
\hline & Granger coefficient & -.0000 & -.0002 & -.000 & -.00012 & -.0000 \\
\hline & $\begin{array}{l}\text { Granger causality p- } \\
\text { value }\end{array}$ & .5537 & $.0519 *$ & .9299 & $.0916^{*}$ & .9197 \\
\hline & $\begin{array}{l}\text { Difference } \\
\text { Sargan/Hensen }\end{array}$ & & & & & 0.99 \\
\hline & $\begin{array}{l}\text { Test of } \beta_{1}+\beta_{2}=0 \mathrm{p}- \\
\text { value }\end{array}$ & .393 & .113 & .717 & .346 & .800 \\
\hline \multirow[t]{11}{*}{$\begin{array}{l}\text { (b) } x=\text { DEA cost } \\
\text { efficiency }\end{array}$} & LER1 & $\begin{array}{c}.8839 * * * \\
(.040)\end{array}$ & $\begin{array}{c}.2058 * * * \\
(.0282)\end{array}$ & $\begin{array}{l}.7684 * * * \\
(.0232)\end{array}$ & $\begin{array}{l}.5722 * * \\
(.2353)\end{array}$ & $\begin{array}{l}.5758 * * * \\
(.2782)\end{array}$ \\
\hline & LER2 & $\begin{array}{l}.0588 * * \\
(.0325)\end{array}$ & $\begin{array}{c}-.1038 * * * \\
(.0279)\end{array}$ & $\begin{array}{l}.1147 * * * \\
(.0225)\end{array}$ & $\begin{array}{l}-.00099 \\
(.0494)\end{array}$ & $\begin{array}{l}.2940 \\
(.2712)\end{array}$ \\
\hline & DEAEFF1 & $\begin{array}{l}-.0004 \\
(.0004)\end{array}$ & $\begin{array}{l}.00023 \\
(.0004)\end{array}$ & $\begin{array}{l}-.00041 \\
(.0004) \\
\end{array}$ & $\begin{array}{l}.00142 \\
(.0016) \\
\end{array}$ & $\begin{array}{l}.00034 \\
(.0005) \\
\end{array}$ \\
\hline & DEAEFF2 & $\begin{array}{c}.0002 \\
(.0004) \\
\end{array}$ & $\begin{array}{c}.0006^{* * *} \\
(.0004)\end{array}$ & $\begin{array}{c}.0002 \\
(.0004) \\
\end{array}$ & $\begin{array}{l}.00094 \\
(.0007) \\
\end{array}$ & $\begin{array}{l}.0004 \\
(.0005) \\
\end{array}$ \\
\hline & $\mathrm{m} 1 \mathrm{p}$-value & .334 & $\mathrm{n} / \mathrm{a}$ & $\mathrm{n} / \mathrm{a}$ & .045 & .477 \\
\hline & $\mathrm{m} 2 \mathrm{p}$-value & $\mathrm{n} / \mathrm{a}$ & $\mathrm{n} / \mathrm{a}$ & $\mathrm{n} / \mathrm{a}$ & .956 & .413 \\
\hline & $\begin{array}{l}\text { Sargan/Hensen p- } \\
\text { value }\end{array}$ & $\mathrm{n} / \mathrm{a}$ & $\mathrm{n} / \mathrm{a}$ & $\mathrm{n} / \mathrm{a}$ & .201 & .853 \\
\hline & Granger coefficient & -.00019 & .0009 & -.0002 & .0024 & .0007 \\
\hline & $\begin{array}{l}\text { Granger causality p- } \\
\text { value }\end{array}$ & .4341 & .203 & .493 & .4032 & .632 \\
\hline & $\begin{array}{l}\text { Difference } \\
\text { Sargan/Hensen }\end{array}$ & & & & & 0.599 \\
\hline & $\begin{array}{l}\text { Test of } \beta_{1}+\beta_{2}=0 \mathrm{p}- \\
\text { value }\end{array}$ & .324 & .116 & .472 & .27 & .342 \\
\hline
\end{tabular}

Note: Year dummies are included in all models. OLS= Ordinary Least Squares; DIF-GMM= difference GMM. SYSGMM = system GMM. SFAEFF= cost efficiency estimated using SFA. DEAEFF= cost efficiency estimated using DEA. $*, * *, * * *$ indicates significance at the $10 \%, 5 \%$ and $1 \%$ levels. Asymptotic standard error in parentheses. HuberWhite standard errors are computed for one-step estimates while the two-step estimates are Windmeijeier corrected. $\mathrm{m} 1$ and $\mathrm{m} 2$ are tests for first-order and second-order serial correlation. Sargan/Hensen is a test of the over-identifying restrictions for the GMM estimators. All computations done using Stata. 
Table 6

Does Competition Granger-Cause Cost Efficiency?

\begin{tabular}{|c|c|c|c|c|c|c|}
\hline $\begin{array}{l}\text { Dependent } \\
\text { variable } y \text { : } \\
\text { COST } \\
\text { EFFICIENCY }\end{array}$ & Variables and tests & OLS levels & $\begin{array}{l}\text { Fixed } \\
\text { Effects }\end{array}$ & $\begin{array}{l}\text { Random } \\
\text { Effects }\end{array}$ & $\begin{array}{c}\text { DIF-GMM } \\
\text { t-2 } \\
\text { Robust }\end{array}$ & $\begin{array}{c}\text { Two-step } \\
\text { SYS-GMM } \\
\text { Robust }\end{array}$ \\
\hline \multirow[t]{11}{*}{$\begin{array}{l}\text { (a) } x=\text { SFA cost } \\
\text { efficiency }\end{array}$} & SFAEFF1 & $\begin{array}{c}2.088 * * * \\
(.0022)\end{array}$ & $\begin{array}{c}2.0764 * * * \\
(.0004)\end{array}$ & $\begin{array}{c}2.0837 * * * \\
(.0003)\end{array}$ & $\begin{array}{c}2.0738 * * * \\
(.0019)\end{array}$ & $\begin{array}{c}2.0875 * * * \\
(.0036)\end{array}$ \\
\hline & SFAEFF2 & $\begin{array}{c}-1.090 * * * \\
(.0023)\end{array}$ & $\begin{array}{c}-1.079 * * * \\
(.0004)\end{array}$ & $\begin{array}{c}-1.0858 * * * \\
(.0004)\end{array}$ & $\begin{array}{c}-1.0759 * * * \\
(.0019)\end{array}$ & $\begin{array}{c}-1.0897 * * * \\
(.0037)\end{array}$ \\
\hline & LER1 & $\begin{array}{l}.01280 \\
(.0093)\end{array}$ & $\begin{array}{l}-.0008 \\
(.0019) \\
\end{array}$ & $\begin{array}{c}-.0021 \\
(.0024) \\
\end{array}$ & $\begin{array}{c}.0008 \\
(.0151) \\
\end{array}$ & $\begin{array}{c}.0006 \\
(.0048) \\
\end{array}$ \\
\hline & LER2 & $\begin{array}{l}.0141 \\
(.0100)\end{array}$ & $\begin{array}{l}.0066^{* * *} \\
(.0019)\end{array}$ & $\begin{array}{c}.0034 \\
(.0024)\end{array}$ & $\begin{array}{c}.0049 * * * \\
(.0028)\end{array}$ & $\begin{array}{c}-.0066^{* * *} \\
(.0036)\end{array}$ \\
\hline & $\begin{array}{l}\text { Serial correlation } \\
\text { (AR1) p-value }\end{array}$ & .0000 & $\mathrm{n} / \mathrm{a}$ & $\mathrm{n} / \mathrm{a}$ & .000 & .001 \\
\hline & $\begin{array}{l}\text { Serial Correlation } \\
\text { (AR2) p-value }\end{array}$ & $\mathrm{n} / \mathrm{a}$ & $\mathrm{n} / \mathrm{a}$ & $\mathrm{n} / \mathrm{a}$ & .000 & .002 \\
\hline & $\begin{array}{l}\text { Sargan/Hensen p- } \\
\text { value }\end{array}$ & $\mathrm{n} / \mathrm{a}$ & $\mathrm{n} / \mathrm{a}$ & $\mathrm{n} / \mathrm{a}$ & .449 & .841 \\
\hline & Granger coefficient & -.0013 & .0058 & .0013 & .0057 & -.0059 \\
\hline & $\begin{array}{l}\text { Granger causality p- } \\
\text { value }\end{array}$ & .2206 & $.0017 * *$ & .330 & .1998 & .1565 \\
\hline & $\begin{array}{l}\text { Difference } \\
\text { Sargan/Hensen }\end{array}$ & & & & & 0.163 \\
\hline & $\begin{array}{l}\text { Test of } \beta_{1}+\beta_{2}=0 p- \\
\text { value }\end{array}$ & .911 & .011 & .660 & .722 & .205 \\
\hline \multirow[t]{11}{*}{$\begin{array}{l}\text { (b) } x=\text { DEA } \\
\text { cost efficiency }\end{array}$} & DEAEFF1 & $\begin{array}{c}.6711 * * * \\
(.0378)\end{array}$ & $\begin{array}{c}.0456 * * * \\
(.0381)\end{array}$ & $\begin{array}{c}.6017 * * * \\
(.028)\end{array}$ & $\begin{array}{l}.5400 * * * \\
(.2026)\end{array}$ & $\begin{array}{l}.7783 * * \\
(.4121)\end{array}$ \\
\hline & DEAEFF2 & $\begin{array}{c}.1721 * * * \\
(.0376)\end{array}$ & $\begin{array}{l}-.1146 \\
(.0348)\end{array}$ & $\begin{array}{c}.1855^{* * *} \\
(.028)\end{array}$ & $\begin{array}{c}.0944 \\
(.0707)\end{array}$ & $\begin{array}{l}.4717 \\
(.4275)\end{array}$ \\
\hline & LER1 & $\begin{array}{c}3.9751 \\
(2.5051) \\
\end{array}$ & $\begin{array}{l}4.4103^{*} \\
(2.5743) \\
\end{array}$ & $\begin{array}{l}4.221 * * \\
(1.8137) \\
\end{array}$ & $\begin{array}{l}-36.8735 \\
(31.7019) \\
\end{array}$ & $\begin{array}{c}2.3988 \\
(2.7498) \\
\end{array}$ \\
\hline & LER2 & $\begin{array}{c}.0295 \\
(2.6762)\end{array}$ & $\begin{array}{c}-1967 \\
(2.5451)\end{array}$ & $\begin{array}{c}-.1512 \\
(1.7705)\end{array}$ & $\begin{array}{l}-6.5340 \\
(5.2405)\end{array}$ & $\begin{array}{l}2.2130 \\
(3.6485)\end{array}$ \\
\hline & $\begin{array}{l}\text { Serial correlation } \\
\text { (AR1) p-value }\end{array}$ & .497 & $\mathrm{n} / \mathrm{a}$ & $\mathrm{n} / \mathrm{a}$ & .003 & .590 \\
\hline & $\begin{array}{l}\text { Serial Correlation } \\
\text { (AR2) p-value }\end{array}$ & $\mathrm{n} / \mathrm{a}$ & $\mathrm{n} / \mathrm{a}$ & $\mathrm{n} / \mathrm{a}$ & .151 & .401 \\
\hline & $\begin{array}{l}\text { Sargan/Hensen } \mathrm{p}- \\
\text { value }\end{array}$ & $\mathrm{n} / \mathrm{a}$ & $\mathrm{n} / \mathrm{a}$ & $\mathrm{n} / \mathrm{a}$ & .000 & .201 \\
\hline & Granger coefficient & $4.005 * * *$ & 4.2136 & $4.070 * * *$ & -43.4075 & 4.6118 \\
\hline & $\begin{array}{l}\text { Granger causality p- } \\
\text { value }\end{array}$ & .001 & .2143 & .001 & .4060 & .4521 \\
\hline & $\begin{array}{l}\text { Difference } \\
\text { Sargan/Hensen }\end{array}$ & & & & & 0.011 \\
\hline & $\begin{array}{l}\text { Test of } \beta_{1}+\beta_{2}=0 \mathrm{p}- \\
\text { value }\end{array}$ & .000 & .1750 & .000 & .217 & .232 \\
\hline
\end{tabular}

Note: Year dummies are included in all models. OLS= Ordinary Least Squares; DIF-GMM= difference GMM. SYSGMM = system GMM. SFAEFF= cost efficiency estimated using SFA. DEAEFF= cost efficiency estimated using DEA. $* * * * * *$ indicates significance at the $10 \%, 5 \%$ and $1 \%$ levels. Asymptotic standard error in parentheses. HuberWhite standard errors are computed for one-step estimates while the two-step estimates are Windmeijeier corrected. $\mathrm{m} 1$ and $\mathrm{m} 2$ are tests for first-order and second-order serial correlation. Sargan/Hensen is a test of the over-identifying restrictions for the GMM estimators. All computations done using Stata. 
Figure 1

Marginal Cost and Lerner Index of Monopoly Power

Marginal Cost

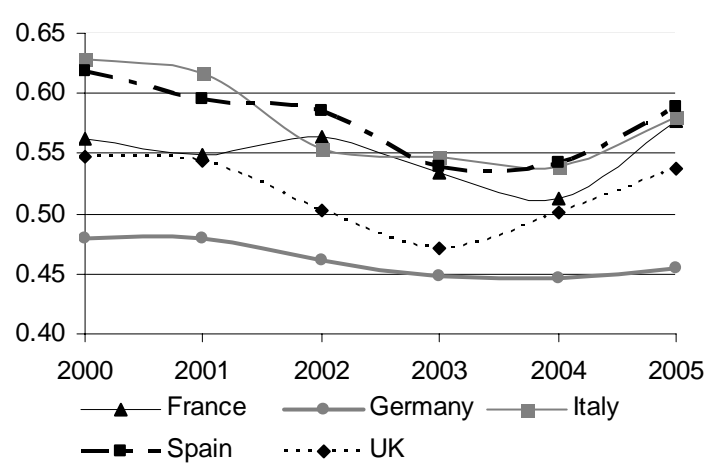

Lerner Index of Monopoly Power

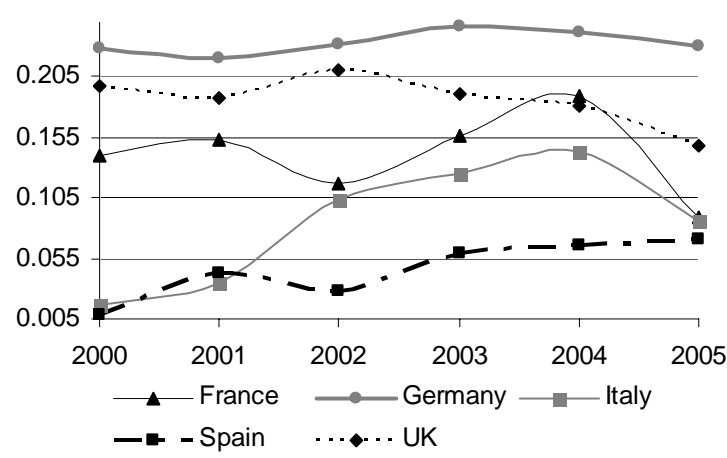


Figure 2

DEA and SFA Yearly Averages

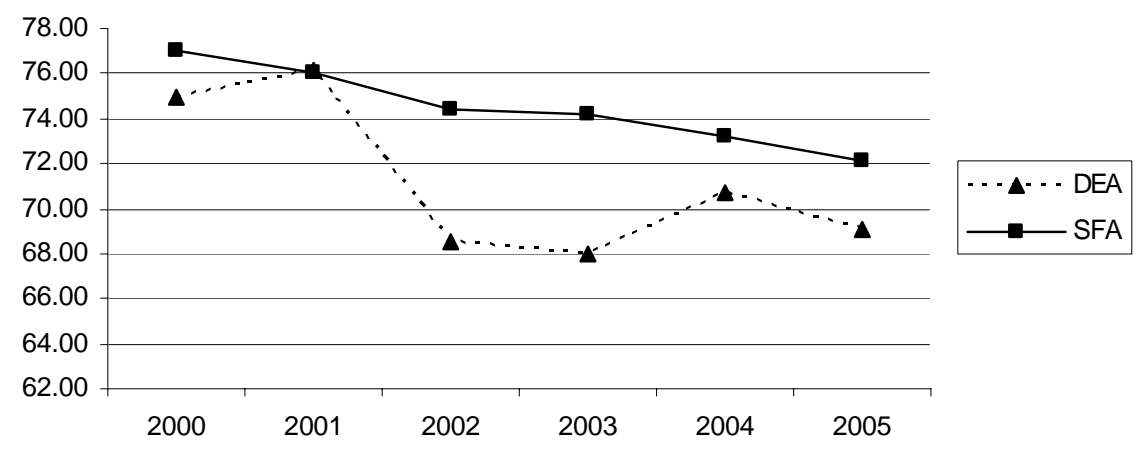

